\title{
THE ADMISSIBILITY AND SCOPE OF GUILTY PLEAS IN ANTITRUST TREBLE DAMAGE ACTIONS
}

\author{
O treble woe \\ Fall ten times treble on that cursed head. \\ Hamlet, Act V, Scene I.
}

IN entering pleas of guilty ... Westinghouse wishes to make it clear that it does not hereby admit the allegations of those indictments . . . .

In this spirit, eighteen electrical manufacturing corporations pleaded guilty in December $1960^{2}$ to charges of violating section 1 of the Sherman Act. ${ }^{3}$ No plea of guilty had ever before been entered by a corporate defendant in a major criminal antitrust prosecution 4 because nolo contendere, which admits guilt solely for the purposes of entering judgment, was generally available. But in the electrical cases, the court had responded to the government request to reject nolo pleas and required defendants either to plead guilty or go to trial. Subsequently, many private actions claiming treble damages for

1. Transcript of Discussion on Rearraignment and Entry of Nolo Contendere Pleas, p. 395 (on file in Yale Law Library). United States v. General Elec. Co., Trade Reg. Rep. (1960 Trade Cas.) I 69699 E.D. Pa., May 13 , 1960 summarizes the hearings.

2. Most of the pleas were entered December 8, 1960, in the United States District Court for the Eastern District of Pennsylvania. The indictments covered 20 products, and charged 29 corporations and 45 individual defendants. See generally, N.Y. Times, Dec. 9, 1960 , p. 1, col. 5 The eighteen corporations which pleaded guilty to at least one of the indictments are: Westinghouse Electric Corporation; Allis-Chalmers Manufacturing Co.; General Electric Co.; McGraw, Edison Co.; Maloney Electric Co.; Wagner Electric Corp.; Federal-Pacific Co.; The Clark Controller Co.; Cutler-Hammer, Inc.; Southern States Equipment Corporation; Foster Wheeler Corp.; Ingersoll Rand Co.; C.H. Wheeler Manufacturing Co.; Worthington Corp.; I-T-E Circuit Breaker Co.; Allen-Bradley Co.; Square-D Co.; H.K. Porter Co.

3. 26 Stat. 209 (1914), 15 U.S.C. \$ 1 (1958).

4. Hadlick, Criminal Prosecution Under the Sheriran Antr-Trust Act App. A (1939), collects case histories before 1939. A search through the Trade Regulations Rcporter covering the past two decades revealed no significant case in which guilty was the plea.

5. In 1953, the Justice Department reversed its prior practice and announced a general policy of opposing nolo pleas because of their limited usefulness in subsequent litigation and their moral ambiguity in areas of flagrant violation where lines of guilt should be clearly drawn. See Memorandum to United States Attorneys from the Attorney General, quoted in United States v. Jones, 119 F. Supp. 288 n.1 (S.D. Cal. 1954) :

One of the factors which has tended to breed contempt for federal law enforcement in recent times has been the practice of permitting ... the plea of nolo contendere. ... Uncontrolled use of the plea has led to shockingly low sentences and insignificant fines which are no deterrent to crime. As a practical matter is accomplishes little that is useful .... Moreover, a person permitted to plead nolo contendere admits guilt for the purpose of imposing punishment for his acts and yet, for all other purposes, and as far as the public is concerned, persists in the denial of wrongdoing. It is no wonder that the public regards consent to such a plea by the Government as 
injuries resulting from the conspiratorial acts involved in the Sherman Act cases have been filed against these manufacturers. ${ }^{6} \mathrm{~A}$ major issue before the courts which try the private suits in the coming years will be what effect a guilty plea in a criminal case should have in third party litigation.

One theory on which a third party plaintiff may rely in tendering the defendant's guilty plea is that section 5 of the Clayton Act ${ }^{7}$ specifically authorizes the introduction of government-obtained judgments as prima facie evidence in treble damage suits. Section 5 declares that:

A final judgment or decree ... rendered in any civil or criminal proceeding brought by or on behalf of the United States under the antitrust laws ... shall be prima facie evidence against such defendant in any action or proceeding brought by any other party against such defendant under said laws ... as to all matters respecting which said judgment or decree would be an estoppel as between the parties thereto.

But a proviso states that "This section shall not apply to consent judgments or decrees entered before any testimony has been taken." The crucial question is

an admission that it has only a technical case at most and that the whole proceeding was just a fiasco....

Accordingly, ... you are instructed not to consent to it except in the most unusual circumstances and then only after your recommendation for doing so has been reviewed and approved by the Assistant Attorney General responsible or by my Office....

Compare the statement of Acting Assistant Attorney General Bicks in the electrical cases: .... [W] ] should urge this court to exercise its discretion in these cases against the acceptance of these nolo pleas. This position . . . is based solely on the seriousness of the crimes these indictments charge....

Our position is that public interest in effective law enforcement, in deterring the occurrence of like flagrancies in the future by these defendants and others . . . suggests refusal on the part of this court to accept nolo pleas.

United States v. General Electric Co., Trade Reg. Rep. (1960 Trade Cas.) I 69699 E.D. Pa., May 13, 1960. Though the policy of contesting nolo was followed in the antitrust field, Hansen, The Current Federal Policy in Antitrust Matters, 4 AnTrTrusr BuLL. 541, 554 (1959), the courts have been largely unimpressed by the arguments and have allowed nolo pleas despite government objections. See, e.g., United States v. Safeway Stores, 20 F.R.D. 451 N.D. Tex. (1957). But cf. United States v. Standard Ultramarine \& Color Co., 137 F. Supp: 167 (S.D.N.Y. 1955).

Two unusual steps were taken to gain guilty pleas in the electrical cases. The head of the antitrust division came in person to argue at the hearings contesting the nolo pleas and he brought with him a letter from the Attorney General of the United States arguing that the future of criminal antitrust enforcement would suffer greatly if nolo were allowed in these cases of blatant violations. See note 1 supra.

6. Third parties may sue for treble damages under $\S 4$ of the Clayton Act, 38 Stat. 731 (1914), 15 U.S.C. § 15 (1958) superseding similar provisions in the Sherman Act, 26 Stat. 210 (1890) and 28 Stat. 570 (1894). It is estimated that over 200 such suits have already been filed, this representing but a fraction of the potential litigation. See, e.g., N.Y. Times, Dec. 5, 1961, p. 1, col.1 reporting the filing by 44 utility companies of actions asking over $\$ 1$ billion in triple damages.

7. 38 Stat. 731 (1914), 15 U.S.C. \& 16(a) (1958). 
whether the proviso embraces a plea of guilty. Both legislative history and logical statutory construction indicate that a guilty plea falls within the proviso and is therefore outside the scope of the section.

Prior to the enactment of section 5, third parties could not introduce government-obtained judgments as proof of the facts upon which they were based. 8 In response to President Wilson's observation that it was "not fair that the private litigants should be obliged to set up and establish again the facts which the Government has proved," legislation was introduced. ${ }^{0}$ The original House bill made judgments in equity both admissible and conclusive in subsequent third party proceedings. ${ }^{10}$ In the Senate, admissibility was expanded to cover judgments in criminal proceedings as well as decrees in equity, but all judgments were reduced from conclusive to prima facie evidence. ${ }^{11}$ Not until the House and Senate bills were referred to a Conference Committee was the proviso added.

The questions and discussion on the floor of Congress following the introduction of the Conference Committee bill in both houses clearly indicate that the purpose of the proviso was to induce defendants to capitulate to government demands. ${ }^{12}$ As one member of the Committee explained:

[T] he prima facie effect shall not apply to consent judgments . . . before any evidence is introduced .... If the Government brings a suit against a trust ... and it surrenders, we eliminate the effect of the "prima facie" judgment. If it fights and loses then the prima facie effect is given . . . ${ }^{13}$

Though the proviso speaks of "consent judgments or decrees," the phrase was manifestly intended to cover criminal as well as civil judgments. Several Senators opposed the proviso precisely because it would include guilty pleas, thereby exempting them from the section's effect:

When the charges are contested there may be some honest doubt as to whether the defendant trust is guilty: but when the Government com-

8. Buckeye Powder Co. v. DuPont Powder Co., 248 U.S. 55 (1918) (government judgment rendered prior to passage of $\S 5$ held inadmissible).

The majority rule still holds judgments in former criminal cases unavailable in a civil proceeding as proof of facts upon which the judgments were based. See cases collected in Annot., 18 A.L.R.2d 1287 (1951). But there is a trend, in light of the greater burden of proof successfully borne in the criminal case, to accord the prior litigation some evidentiary weight. New York \& Cuba Mail S.S. Co. v. Continental Ins. Co., 117 F.2d 404 (2d Cir. 1941) describes the trend, citing cases, in an addendum to the opinion at 411 . See also excellent Note, 50 Y ALE L.J. 499 (1940). Even cases allowing the use of former litigation as proof of facts, however, fall into a pattern where overriding policy considerations persuade the court to ignore both the lack of mutality and the fact of different parties in each action. See, e.g., Austin v. United States, 125 F.2d 816 (7th Cir. 1942) (beneficiary of insurance policy not allowed to profit from his crime).

9. 51 Cong. REc. 1964 (1914).

10. Id. at 9487.

11. Id. at 13898.

12. See, e.g., id. 15823-25, 16046-47.

13. Id. at 16276 . 
mences a prosecution against a great trust . . . and they . . . come into court and plead guilty, is there any doubt of their guilt?

Then why should consent judgments be excluded?14

These debates on the final bill make clear what was true from the beginning: that Congress had conceived section 5 primarily to relieve third party plaintiffs from the unfairness and waste which had resulted from the necessity of relitigating issues already adjudicated by an expensive trial. ${ }^{15}$ This being so, the addition of the proviso was not inconsistent with the congressional purpose. And, the proviso gave the government a useful tool with which to induce compromise. ${ }^{16}$ It was hoped that defendants fearing future damage actions would waive trial on the government charges in order to deprive third party plaintiffs of the benefit of section 5.17

Despite the legislative history, it might be argued that the language of the proviso in its natural meaning applies only to civil proceedings. "Consent judgments or decrees" are both common in civil proceedings, but the terminology is anomalous in the criminal context. ${ }^{18}$ Another proviso ${ }^{10}$ to section 5 ,

14. Id. at 16046 .

15. Typical of the approach taken even by advocates of aid to third-party litigants is Senator Walsh's comment during the debates on the original Senate bill:

If the United States shall proceed against any organization ... and eventually, after a judicial procecding going through all the $\dot{C}$ ourts, it shall be determined and decided that the organization is a combination in violation of the Sherman Act, that judgment ... can be availed of by anybody .... The party seeking to take advantage of it will not be obliged to retravel again, step by step, over the entire field which it arrived .... In other words, we give to the private individual the benefit which accrues by reason of the long litigation pursued by the Government in endeavoring to secure the judgment.

51 ConG. REC. 13351 (1914). (Emphasis added.)

16. In order to eliminate the cumbersome, dilatory and expensive trials which had bogged down the enforcement of the anti-trust laws, it is expressly provided that a consent judgment entered before any testimony is taken is not to be thus available as prima facie evidence. Thereby, it was hoped that defendants would be persuaded to settle their difficulties out of court on a basis protecting the public interest and yet without draining the scant funds and personnel available for anti-trust work.

Timberg, The Anti-trust Laws front the Point of View of a Government Attorney, Practicing Law Institute 38 (1949).

17. Arguments by counsel in United States v. Safeway Stores, TRADE REG. REP. (1957 Trade Cas.) If 68770 (July 26, 1957), typical of those in other such cases, see, e.g., United States v. B.F. Goodrich Co., id. $\{68713$, indicate that fear of treble damage actions $\mathrm{s}$ a major consideration to defendants in pleading. Bicks, The Department of Justice and Drizate Treble Damage Actions, 4 AnTITRust Bulz. 8 (1959): "The threat of subsequent rrivate litigation may well be a major consideration prompting defendants to enter into :onsent decrees." See Comment, 61 Y ALE L.J. 1010, 1061 n.334 (1952).

18. United States v. Standard Ultramarine \& Color Co., 137 F. Supp. 167, 173 S.D.N.Y. 1955). "[N]o criminal would ever consent that a judgment be entered against im when he pleads guilty." 51 Cong. Rec. 15824 (1914) (remarks of Senator Walsh about he Proviso).

Lenvin and Meyers, Nolo Contendere: Its Nature and Implications, 51 YaLE L.J. 1255, 
however, militates against such a literal reading by demonstrating that Congress in 1914 used the term "consent judgment or decrees" to refer both to criminal and equitable proceedings. This proviso declares that section 5 "shall not apply to consent judgments or decrees rendered in criminal proceedings, or suits in equity now pending ${ }^{20} \ldots$. Fortifying this argument is the consistent action of courts in applying the language of the first proviso to one type of criminal consent judgment, that entered following a plea of nolo contendere. ${ }^{21}$ The rationale is that such judgments are entered before testimony is taken, signifying capitulation, and therefore constitute "consent judgments." 22 Since these characteristics are as typical of guilty pleas ${ }^{23}$ as of nolo pleas and since the judgment entered following a nolo plea is identical to that following a guilty plea, ${ }^{24}$ there is no reason to distinguish them for the purpose of the proviso.

Even though the proviso forecloses efforts to introduce a plea of guilty as prima facie evidence under section 5 of the Clayton Act, the plea may be

$1267 \mathrm{n} .68$ (1942) cites a statement by Judge Bard, in sentencing defendants in United States v. American Waxed Paper Ass'n (E.D. Pa. 1942) that there is no such thing as a consent judgment in a criminal action.

19. Provided, further, this Section shall not apply to consent judgments or decrees rendered in criminal proceedings, or suits in equity now pending in which the taking of testimony has been commenced but has not been concluded, provided such judgments or decrees are rendered before any further testimony is taken.

38 Stat. 731 (1914), 15 U.S.C. \$ 16 (1958).

20. The argument, of course, may cut the other way: when Congress intended to refer to consent judgments in criminal proceedings, it did so specifically. Though persuasive, this construction must give way to the combination against it of legislative history and purpose as well as judicial interpretation. See text at notes $21-23$ infra.

21. See Twin Ports Oil Co. v. Pure Oil Co., 26 F. Supp. 366 (D. Minn. 1939), aff'd, 119 F.2d 747 (8th Cir. 1941), cert. denied, 314 U.S. 644 (1941).

22. 26 F. Supp. 366 (D. Minn. 1939). A second ground for the decision was that 1solo contendere does not create an "estoppel as between the parties" to the Government action. Twin Ports is most often cited, however, for holding that nolo is a consent decree. See, e.g., Barnsdell Ref. Corp. v. Birnamwood Oil Co., 32 F. Supp. 308 (E.D. Wis. 1940).

23. See ibid. Throughout Twin Ports, Judge Nordbye gratuitously considers guilty pleas and finds that they have exactly the same effect as nolo contendere under the Proviso. The effective marshalling of legislative history in the lengthy opinion makes it persuasive dicta on the effect of the guilty plea. But cf. United States v. Standard Utramarine \& Color Co., 137 F. Supp. 167 (S.D.N.Y. 1955) in which Judge Weinfeld viewed aid to the treble-damage litigant as the overriding legislative concern of section 5 and inferred from this that third parties should not be denied the use of guilty pleas by classifying them as "consent judgments." This analysis is as much dicta as that in Trwin Ports since Judge Weinfeld was merely deciding whether to accept a nolo contendere plea; there was no question of the defendant's pleading guilty. But the finding that the section's major purpose is aid to treble-damage litigants and that the proviso must be construed in that light, is a construct of the decision.

24. United States v. Reisfield, 188 F. Supp. 631 (D. Md. 1960) indicates that in the majority of cases even the same printed forms are used for judgments on guilty and nolo pleas. Here, the court accedes to defendant's request to vary the printed form somewhat but admits no substantial difference between the two judgments. 
admissible under the common law admission exception to the hearsay rule. ${ }^{2 \bar{v}}$ Under present rules of evidence, guilty pleas introduced by third parties constitute "some evidence" of the matter deemed to be covered by the plea. ${ }^{26}$ Courts universally entertain defense evidence explaining or contradicting the implications of such pleas, ${ }^{27}$ but the plea alone may be sufficient to carry an issue to the trier of fact. ${ }^{28}$

It may be objected, therefore, that admitting a guilty plea into evidence as a common law admission would for all practical purposes make prima facie evidence out of a judgment which is protected from such effect by the proviso to section 5.29 Admitting such a plea, the argument would continue, implies that Congress went through the empty motions of protecting from the prima facie effect of section 5 certain judgments which would have exactly the same weight if left to operate outside of the section. But the major assumption underlying this argument-that the congressmen who enacted section 5 believed that a common law admission constituted prima facie evidence-may be unwarranted. Many of the evidence treatises current in 1914 omit any consideration of the effect to be given a guilty plea when introduced by a third party in a subsequent civil suit. ${ }^{30}$ Wigmore's first edition, ${ }^{31}$ published in 1904 , classified a guilty plea as a "quasi-admission," 32 generally admissible to demonstrate only that an opponent had previously contradicted his present claim. To be considered "affirmative testimony," states the treatise, the plea must have been against interest at the time it was made. ${ }^{33}$ Nowhere is "affirmative testimony"equated with prima facie evidence. In fact, the treatise refers to a quasi-admission merely as an "item in the mass of evidence." 34 Moreover, extensive case law on the use of guilty pleas was not available. The only significant case cited

25. WigMore, EVIDENCE, $§ \S ~ 815,1066,1067$ (3d ed. 1940).

26. See cases collected in Annot, 31 A.L.R. 278 (1924), Annot., 18 A.L.R.2d 1307 (1951)

27. See, e.g., Race v. Chappell, 304 Ky. 788, 202 S.W.2d 626 (1947); Greenfield v. Tuccillo, 129 F.2d 854 (2d Cir. 1942); Gillespie v. Modern Woodmen, 101 W. Va. 602, 133 S.E. 333 (1926).

28. In case they were made understandingly and deliberately, are of pure fact within the knowledge of the declarant and were made under conditions and circumstances conductive to veracity and are not overborne by the other facts in evidence they may establish a cause of action....

Gangi v. Fradus, 227 N.Y. 452, 457, 125 N.E. 677, 679 (1920), quoted in Bruce v. McClure, 220 F.2d 330 (5th Cir. 1955). The Court here is speaking of admissions generally, but what it says is especially true of guilty pleas. For holding to same effect, see Leusink v. O'Donnell, 257 Wisc. 571, 44 N.W.2d 525.

29. Prima facie simply means that the evidence has sufficient weight if not rebutted to establish the fact for which it is offered. See WrGMORE, EVIDENCE § 2494 (3d ed. 1940).

30. See, e.g., Best, Evidence (1911) ; Elriotr, Evidence (1904); Hughes, Evidence (1907); 1 GreenLeaf, EVIdence 575 n.1 (1842).

31. 1 WigroRe, EVIDENCE (1904).

32. Id. § 815 .

33. 2 WigMORE, EVIDENCE $§ 1048$ (1904).

34. Id. $§ 1057$. 
by Wigmore allowed the former guilty plea as evidence but did not permit the jury to know the allegations of the indictment to which the plea had been directed, and did not employ the phrase "prima facie evidence."35 Thus, Congress might well have believed that a plea of guilty, although admissible under common law rules, was not given prima facie effect by contemporary courts. It is reasonable to assume that Congress enacted section 5 to give prima facie effect to certain judgments which did not have such weight at common law, and that by exempting other judgments from its coverage, Congress intended to leave their admissibility and weight to the development of the common law. ${ }^{36}$ That present courts apparently give common law admissions prima facie effect is irrelevant in determining the intent of Congress in $1914 . .^{37}$ Colloquy during the debates supports this reading of the statute. Senator Norris, for example, made the following comment:

... [N] otwithstanding the Proviso, which says that the section shall not apply to certain cases, suppose that in all other respects, it was proper to offer a judgment in evidence and there was no reason why it should not be admitted, assuming that in other respects the judgment is proper evidence, then this Proviso would not exclude it as I understand. ${ }^{38}$

35. Birchard v. Booth, 4 Wisc. 67 (1855).

36. The language of the proviso supports two further arguments for the admissibility of the pleas as common law admissions. The proviso states that "this section shall not apply to consent judgments" (emphasis added), not, as it easily could have, that consent judgments shall be exempted from evidentiary use in subsequent litigation. Secondly, the proviso refers only to judgments whereas pleas, not judgments, are common-law admissions, since the admission-emphasis is on the defendant's voluntary statement. See note 71 infra.

37. The current Wigmore (1940 ed.) devotes little more space to guilty pleas as admissions than the 1904 edition. See note 24 supra. But the footnotes collect considerably more cases in which the holdings are uniform on the effect of the pleas.

38. 51 CoNG. Rec. 15939 (1914).

Senator Nelson was speaking against the Proviso when Senator Norris asked:

Does not the Senator think, notwithstanding the Proviso ... that the judgments ... could be offered and would be proper evidence, although it might not establish a prima facie case.

Nelson: I do not think so unless the parties should be the same.

Norris: ... (I)t would not necessarily follow that on account of the Proviso a judgment ... could not be offered as evidence if it were otherwise admissible.

Nelson: The effect of the judgment would not be restricted under the general law; but the Senator who himself has been a judge knows very well that where there is not an identity of parties, the judgment could not be used.

Norris: ... I do not think the Senator gets my idea .... Notwithstanding the Proviso, which says that the section shall not apply to certain cases, suppose that in all other respects, it was proper to offer a judgment in evidence and there was no reason why it should not be admitted, assuming that in other respects the judgment is proper evidence, then this Proviso would not exclude it as I understand.

Nelson: No.

But cf. an earlier comment by another Senator which suggested that the Proviso destroyed all evidential weight for the guilty pleas:

You have got no more right to destroy the evidentiary value of a plea of guilty in a 
A number of court of appeals decisions also support this reading by implicitly holding that section 5 does not regulate the entire area of admissibility of judgments in antitrust cases, and thus that judgments specifically exempted from the section may nevertheless have some evidentiary weight. In Pfotzer v. Aqua Systems Inc., ${ }^{30}$ the Second Circuit was squarely confronted with the contention that the proviso to section 5 prevented any subsequent use of consent judgments ;0 the contention was necessarily rejected by the court's holding that evidence of a prior plea of nolo contendere was admissible to impeach a witness. In Vitagraph, Inc. v. Perelman, ${ }^{41}$ the Third Circuit admitted a consent decree which was within the language of the proviso as some evidence of defendants' attitude toward a specific industry practice. The court noted that the "consent decree was not ... prima facie evidence .. . but was simply admitted as a fact in showing the activity of the defendants to prevent double featuring ....",42

Once a court has decided that a plea of guilty should be admissible as a common law admission, it faces the problem of what group of facts the plea should be deemed to have admitted. A defendant who pleads guilty is usually held to have admitted only the essential elements of the offense charged. ${ }^{43}$ The

trust case than in the case of an embezzler or murderer. The evidence in either case can be used without any statute.... This right you have sought to take away in trust suits ....

51 Cong. Rec. 15939.

39. 162 F.2d 779 (2d Cir. 1947).

40. Brief for Appellees, pp. 32-34, Pfotzer v. Aqua Systems, Inc., 162 F.2d 779 (2d Cir. 1947).

41. 95 F.2d 142 (2d Cir. 1938).

42. Id. at 146. MIilgrim v. Loews, Inc., 192 F.2d 579 (3d Cir. 1951) also indicates that $\S 5$ does not cover the field of the admission of former judgments in antitrust cases. The Third circuit here permitted a prior judgment to be used as evidence of a "proclivity" to violate antitrust laws after apparently finding the judgment inadmissible under $\S 5$. Id. at $594 \mathrm{n} .5$ (dissent). One of the objections in the vehement dissent was:

... section 5 of the Clayton Act contains a narrow and precisely defined authorization to use a judgment or decree rendered in a public suit. ... This statute would have been unnecessary if without legislation courts were authorized to make the present far broader use of prior wrongdoing.

United States v. Lake Asphalt and Petroleum Co., Trade Reg. Rep. (1960 Trade Cas.) I 69835 (D. Mass. Nov. 11, 1960) adds a further fillip to the whole issue of section 5 regulation of the admissibility of prior anti-trust judgments. In this case the Government engineered a compromise in which defendants were allowed to enter nolo contendere pleas without government protest, but the judgment contained an injunction restraining the defendant from denying prima facie effect in subsequent suits against it by Massachusetts and its political subdivisions. Effectively, judgment on a nolo contendere plea was potentially given section 5 effect though congressional intent and judicial interpretation had agreed that such pleas should fall within the proviso. In view of a court's allowance of this procedure, it becomes difficult to argue any absoluteness for the language of section 5 . See generally McHenry, The Asphalt Clause-A Trap for the Unwary, 36 N.Y.U.L. REv. 1114 (1961).

43. See, e.g., Hawley v. Hunter, 161 F.2d 825 (10th Cir. 1947). 
difficulty, especially in conspiracy cases, lies in determining which of the facts alleged in the indictment are "essential." The antitrust indictments lodged against defendants in the recent General Electric case illustrate the difficulty and the importance of this question. ${ }^{44}$

Paragraph 9 of the indictment in case No. 20235 charged that since 1951 defendants have "engaged in a combination and conspiracy in unreasonable restraint of the ... interstate trade and commerce in circuit breakers, in violation of Section 1 of the ... Sherman Act." Paragraph 10 charged that "the aforesaid combination and conspiracy has consisted of a continuing agreement, understanding and concert of action ... the substantial terms of which have been and are: (a) To fix and maintain prices ... of circuit breakers; (b) To allocate among themselves the business of supplying circuit breakers to Federal, State, and local government agencies; (c) To submit ... rigged bids [for such governmental sales] ; and (d) To submit . . . rigged price quotations ... [for sales to electric utility companies]." Paragraph 11 charged the defendant with having done a number of carefully detailed things "for the purpose of forming and effectuating the aforesaid combination and conspiracy." 45 Final paragraph 12 alleged that as a result of the conspiracy (a) the prices of circuit breakers had been fixed, (b) competition in the sale

44. United States v. General Elec. Co., Criminal Action No. 20235, filed Feb. 16, 1960, charging a conspiracy in the trade of circuit breakers against five corporate defendants. (On file in the Yale Law Library).

45. During the period of time covered by this indictment, the defendants, and other persons to the grand jurors unknown, for the purpose of forming and effectuating the aforesaid combination and conspiracy, have done, among other things, the following :

(a) Since at least 1951, and continuing until sometime in 1957 , representatives of defendant manufacturers, [naming 4 defendants] conducted frequent meetings. In 1956 at least nine such meetings were held at hotels in various cities throughout the country including New York, N.Y., Pittsburgh, Pa., Boston, Mass. and Philadelphia, Pa.;

(b) The aforesaid meetings were conducted for the purpose of allocating among the manufacturers sales of circuit breakers to various Federal, State and local governmental agencies pursuant to sealed bid invitations. The bid invitations were allocated ... as follows:

$\begin{array}{ll}\text { General Electric } & 45 \% \\ \text { Westinghouse } & 35 \% \\ \text { Allis-Chalmers } & 10 \% \\ \text { Federal Pacific } & 10 \%\end{array}$

Particular bid invitations were discussed and one of the manufacturers was designated to submit the lowest bid for each invitation....

(c) From January through October of 1958 , representatives of defendant manufacturers ... met periodically in at least seven meetings to discuss increases in the price levels for circuit breakers...

(d) In the fall of 1958, all of the defendant manufacturers agreed to discontinue the sale of circuit breakers at the then prevailing lower prices. On or about November 9, 1958, a meeting was held at the Traymore Hotel, Atlantic City, N.J., at which 
of circuit breakers suppressed, and (c) purchasers deprived of the benefits of free competition in circuit breakers.

representatives of all of the defendant manufacturers agreed, among other things, that:

(1) In the sale of circuit breakers to non-governmental organizations, all of the defendant manufacturers, except I-T-E Circuit Breaker Company, would sell circuit breakers at "list" or "book" prices which prices were substantially identical for all defendant manufacturers;

(2) Representatives of all of the defendant manufacturers would meet periodically and allocate bids to Federal, State and local governmental agencies, according to the following approximate percentage shares:

$\begin{array}{lr}\text { General Electric } & 40.3 \% \\ \text { Westinghouse } & 31.3 \% \\ \text { Federal Pacific } & 15.6 \% \\ \text { Allis-Chalmers } & 8.8 \% \\ \text { I-T-E } & 4.0 \%\end{array}$

(e) On or about November 12, 1958, at Atlantic City, N.J., and on or about November 15, 1958 at Philadelphia, $\mathrm{Pa}$., meetings were held for the purpose of establishing a systematic procedure for carrying out the agreements reached at the November 9, 1958 meeting. At these meetings, defendant manufacturers also agreed that the "list" or "book" price of circuit breakers should not include certain accessory items, but that additional charges should be made for those items ;

(f) Commencing thereafter, a series of periodic meetings were held throughout the country, attended by representatives of all of the defendant manufacturers. At least nine such meetings were held between December 1958 and September 1959 at various cities including Philadelphia, New York, Chicago, Seattle and Denver;

(g) At these periodic meetings, a cumulative list of sealed bid business secured by all of the defendant manufacturers was circulated, and the representatives present would compare the relative standing of each company . . . The representatives present would then discuss particular future bid invitations and designate which manufacturer should submit the lowest bid therefor;

(h) At these meetings, the manufacturer designated to receive a particular sale would then declare the price at which it intended to bid. If the designated manufacturer had not yet computed its bid, its representative would later notify the other representatives usually by correspondence or telephone, stating the specific figure which he would quote on the bid invitation and describing the equipment involved. In the course of these communications, various procedures were used for the purpose of avoiding detection . . . . a code number ... as the sole identification of the sender or in conjunction with the use of the first name of its representative;

(i) It has been the normal practice for the designated manufacturer to submit its bid at a price based upon the "list" or "book" price of the basic circuit breaker unit involved and for the other defendant manufacturers to submit higher bids usually by adding additional items in their computations. On various bid invitations, usually involving a relatively small sales value, the defendant manufacturers agreed to submit identical bids at "list" or "book" prices; and

(j) Pursuant to these agreements the defendant manufacturers submitted bids in 1958 and 1959 to various Federal, State, and local governmental agencies and Ibid. other awarding authorities throughout the United States. 
How much of such an indictment does the guilty plea encompass? Should the defendant be held to have admitted only that his conduct fell within the statutory definition of the crime charged? (This would be equivalent to admitting Paragraph 9 alone.) Or should he be held to have confessed to specifically charged conduct which, as a matter of law, constituted a crime? (This would be equivalent to admitting participation in a specific type of conspiracy definable by its purposes as catalogued in Paragraph 10 and perhaps by the acts performed "for the purpose of forming and effectuating" it as set forth in Paragraph 11.) Or should he be held to have admitted not only the offense charged, either in the language of the statute or as defined by the indictment, but also whatever collateral charges may have been made in the indictment? (This would be equivalent to admitting the effects of the conspiracy alleged in Paragraph 12.) The specificity of allegations admitted by a guilty plea greatly concerns third party plaintiffs seeking to use the plea because treble damage actions must be grounded on proof of particular conduct which has demonstrably injured the complainant. ${ }^{46}$

Some indication of the scope the guilty pleas will have as admissions may be discernible from the extent to which the pleas estop defendants in government damage actions, ${ }^{47}$ which will be litigated before most of the third party treble damage suits come to trial. In both instances the courts will confront many of the same difficulties, since basic to both estoppel and common law admissions is the question: What facts alleged in an indictment were so essential to the crime charged that they should be considered as admitted in subsequent proceedings stemming from the same conduct? Thus, the resolution of "essentiality" for estoppel purposes could influence the later admissive effect of guilty pleas.

The scope of the estoppel created by former criminal judgments is a function of the judgment, the indictment, and (if there has been a trial) the evidence and instructions to the jury. ${ }^{48}$ Only an examination of all such

46. Suckow Borax Mines Consol. Inc. v. Borax Consol. Ltd., 185 F.2d 196, 208 (9th Cir. 1950). The statute authorizing treble-damage litigation, see note 6 supra, gives a cause of action to one "injured in his business or property." Thus, it is not enough for a plaintiff to allege a general violation of the anti-trust laws without demonstrating specifically how his injury resulted. Hadetck, Treble Damages Under the Antitrust LAws 14-17 (1940). See also, Timberlake, The Use of Government Obtained Judgments or Decrees in Subsequent Treble Damage Actions Under the Antitrust Laws, 36 N.Y.U.L. REv. 991, 992-993 (1961) for extensive case citation on the nature of the private plaintiff's cause of action.

47. The Government is bringing civil suits for double damages under the False Claims Act, 12 Stat. 696 (1863), 31 U.S.C. \$\$ 231-33 (1958), and for compensation under § $4 a$ of the Clayton Act, supra note 6 (1955 amendment allowing Government a cause of action for actual damages). See, e.g., Civil Complaint No. 29379, United States v. General Elec. Co., filed E.D. Pa., March 14, 1961 (on file in Yale Law Library).

48. A sampling of Supreme Court cases reveals the range of materials which can be used in determining what matters were previously adjudicated: Sealfon v. United States, 332 U.S. 575 (1948) (evidence at trial and instructions to jury); Oklahoma v. Texas, 256 U.S. 70 (1921) (record) ; Radord v. Meyers, 231 U.S. 725 (1914) (opinion); Last Chance Mining Co. v. Tyler Mining Co., 157 U.S. 683 (1895) (findings and conclusion) ; Russell v. Place, 94 U.S. 606 (1876) (extrinsic evidence). 
sources can reveal the outer limits of the prior judgment, the extent to which it was an adjudication of the details of the charged offense rather than of some unidentified acts violating the relevant statute. ${ }^{49}$ One result is that the scope of the estoppel depends as much upon how the indictment is drawn and what evidence is adduced as it does upon the nature of the offense itself. 50 To some extent, therefore, the prosecutor can control the scope of the judgment's subsequent estoppel. Limiting this control is the tactical necessity of framing an indictment which will maximize the likelihood of conviction.

Two conceptual difficulties result from an attempt to estop a defendant from denying particular overt acts after he has pleaded guilty to a Sherman Act conspiracy indictment alleging those acts. An overt act (in addition to the agreement) is not an essential element of a Sherman Act conspiracy, thus allegations of such acts in the indictment could be regarded as surplusage, not covered by the defendant's plea of guilty. ${ }^{51}$ Secondly, when an indictment includes enumerated terms, purposes, acts, or results, and conviction could be sustained by the establishment of some but not all of the enumerated items, a judgment before trial on a plea of guilty is not an adjudication of any particular one of the alleged items. ${ }^{52}$

49. Emich v. United States, 340 U.S. 558 (1951), illustrates estoppel technique. A treble-damage plaintiff sought to introduce a government-obtained judgement under $\S 5$. The heart of his case was that cancellation of his dealer-franchise had resulted from refusal to finance his sales through General Motors Acceptance Corporation. Emich introduced the judgment against G.M. showing a conspiracy to limit interstate trade in respect to monopolizing auto-financing. The Court of Appeals, 181 F.2d 70 (7th Cir. 1950), found the judgment inadmissible to show that coercion of dealers was one of the means employed in the conspiracy. The Supreme Court reversed, holding that the finding of coercion against dealers was firmly rooted in the criminal conviction and that it could therefore be introduced as prima façie evidence under section 5, thus easing Emich's proof problems on the cause of the franchise cancellation. In determining the reach of estoppel, the Court counseled lower courts to "examine the record, including the pleadings, the evidence submitted, the instructions under which the jury arrived at its verdict and any opinions of the courts." Id. at 569. Emich is well explored in Notes, 62 Y ALE L.J. 417 (1952), 65 Harv. L. Rev. 1400 (1952), 46 ILL. L. REv. 765 (1951).

50. See, c.g., United States v. Ben Grunstein \& Sons, 127 F. Supp. 907 (D. N.J. 1955) in which the court suggests that it is a matter of interpretation whether any particular act is an essential characteristic of a conspiracy or one of the means used to effectuate it. In Sealfon v. United States, 332 U.S. 575 (1948), the Court looked partly to the "facts adduced at trial" to determine estoppel.

51. Nash v. United States, 229 U.S. 373, 378 (1918) ; United States v. Socony-Vacuum Oil Co., 310 U.S. 150, 224 n.59 (1940). See generally on Sherman Act conspiracies, Rahl, Conspiracy and the Anti-Trust Laws, 44 ILz. L. Rev. 743 (1950); Note, 13 Geo. WASH. L. Rev. 434 (1948); Note, The Nature of a Sherman Act Conspiracy, 54 Colum. L. Rev. (1954).

52. United States v. American Packing Co., 113 F. Supp. 223 (D. N.J. 1953), United States v. Ben Grunstein \& Sons Co., 127 F. Supp. 907 (D. N.J. 1955), United States v. Guzzone, 273 F.2d 121 (2d Cir. 1959). Since these three cases struggle with interpreting a plea of guilty to conspiracy in a subsequent suit predicating liability on the plea, they are of particular interest, and because so apposite will be much cited in subsequent documentation. In each case, the Government was seeking to recover damages in a civil suit follow- 
These difficulties, however, do not foreclose the possibility of estopping a party from denying a substantial portion of the details of an indictment to which he has pleaded guilty. ${ }^{53} \mathrm{~A}$ defendant by pleading guilty admits a specific offense, not just commission of a type of crime generally. ${ }^{54}$ An indictment, moreover, must go beyond the general statutory prohibitions and charge an offense in specific terms. ${ }^{55}$ Thus, a Sherman Act indictment cannot charge solely in terms of the statute "a conspiracy in restraint of trade in electrical equipment," but must "descend to particulars" about the act or agreement. How far an indictment must "descend" is a question courts are constantly, variously and somewhat inarticulately, deciding when Sherman Act indictments

ing a criminal conviction for a conspiracy to file false claims against it. In order to show damages, the government needed proof of the specific acts originally alleged as part of the conspiracy. The courts categorically refused to read the criminal indictments so broadly. Rather, they took the view that:

The specification of illegitimate activities appended to the bald charge of conspiracy may be considered in the nature of a bill of particulars, advising the accused of the acts upon which the Government bases its denunciation.

United States v. American Packing Co., supra at 224. Since only one overt act was necessary to prove the conspiracy and the indictment had alleged many such acts, neither all nor any particular one had been proved.

If the same indictment were to go to trial, the scope of the estoppel resulting from the judgment might be expanded because the prosecution might choose to present proof of but one of the enumerated items or the defendant might not contest some of them. See, e.g., United States v. Sealfon, 332 U.S. 575 (1948). But it is doubtful whether even after trial the defendants could be bound by a judgment, insofar as independently sufficient enumerated items were concerned, if evidence has been adduced as to more than one of the listed items, and if the defendant had contested all the issues toward which Government evidence had been directed (or, at least the item on which it is later sought to estop him). United States v. Socony-Vacuum Oil Co., 310 U.S. 150, 250 (1940).

53. See, e.g., United States v. Bower, 95 F. Supp. 19 (E.D. Tenn. 1951), United States v. Schneider, 139 F. Supp. 826 (S.D.N.Y. 1956). When the defendants in subsequent suits denied that their guilty pleas covered certain acts, the court simply found that they had pleaded to all important allegations in the indictment (important not necessarily meaning material). Neither case, however, involved conspiracy where the dichotony between the act of agreement and the acts done in pursuance thereof is clear enough to make courts reluctant to go beyond the statutory language defining the conspiracy. See cases cited at note 45 supra. Moreover, in the Bower and Schneider cases, the main issue was liability for a statutory forfeiture rather than proof of damages. Refusing the defendant the right to deny portions of the indictment to which he had formerly pleaded guilty did not directly affect the liability issue, since the Government needed no proof of specific acts on which to base damage claims. See, also, the court's craftsmanship in interpreting the meaning of a guilty plea in United States v. Wainer, 211 F.2d 667 (7th Cir. 1954).

54. But, of course, the conspiracy as charged means the admission of that particular conspiracy in its essential nature, else the pleading defendants could not later plead double jeopardy to another indictment of the same nature....

United States v. Ben Grunstein \& Sons, 127 F. Supp. 907, 910 (D. N.J. 1955).

55. United States v. Cruickshank, 92 U.S. 542 (1875).

56. Frankfort Distilleries v. United States, 144 F.2d 824 (10th Cir. 1944), aff'd, United States v. Frankfort Distilleries, 324 U.S. 293 (1945). 
are challenged as to sufficiency. ${ }^{57}$ The decisions agree, however, that some details describing the conspiracy must be set forth. In United States v. Armour $\mathcal{G}$ Co., ${ }^{\sigma 8}$ for example, the court said that though a paragraph charging that the "defendants continuously for a period of ten years knowingly engaged in a conspiracy ... to fix prices of hogs in Oklahoma City market in restraint of trade in violation of Section 1 of the Sherman Act" would be "insufficient to charge the offense with the definiteness and clarity required by law," the next two paragraphs saved the indictment. Allegations in the first of these paragraphs included :

defendants ... purchase equal number of hogs each year and each month in the aforesaid livestock market; defendants divide . . . shipments equally between themselves and pay identical prices for the hogs in the shipments so divided; . . . defendants regulate their Saturday buying of hogs in the aforesaid market on a reciprocal basis ; . . defendants threaten to cease purchasing hogs from commission firms selling to other buyers of hogs .... and in other ways obstruct and impede the lawful buying and selling liberties of such commission firms ...."

The second of the paragraphs sets forth a number of overt acts done to "effectuate the conspiracy."

Generally, the sufficiency of a conspiracy indictment is measured by its success in defining the nature of the conspiratorial agreement, in enabling the defendant to prepare his case, and in protecting the defendant from double jeopardy. ${ }^{60}$ Courts, of course, vary in their decisions on sufficiency. But the one uniform standard is that the indictment must charge a particular crime with particular attributes. ${ }^{01}$ One does not plead guilty, therefore, to conspiracy in the air, but rather to a specific, though perhaps tacit or inferred, agreement between specific parties to do specific things during a specific period. A conspiracy between $A, B$, and $C$ is not identical to nor proved by evidence of a conspiracy between $A$ and $B$ : a conspiracy to do $X, Y$, and $Z$ is not a conspiracy to do $X$ and $Y$ only; nor is a conspiracy from $T^{1}$ to $T^{2}$ identical to a conspiracy from $T^{1}$ to $T^{3}$ or vice versa. It may be that if a defendant goes to trial on a conspiracy indictment, his conviction will be sustained notwith-

57. Compare United States v. Safeway Stores, 57 F. Supp. 448 (D. Kan. 1943) with United States v. Erie County Malt Beverage Ass'n, Trade Reg. Rep., (1957 Trade Cas.) I 68590 (W.D. Pa. Jan. 25, 1957).

58. 137 F.2d 269 (10th Cir. 1943).

59. Other cases have held sufficient indictments charging no more than the paragraph Armour suggests was insufficient standing alone. See, e.g., United States v. Erie County Malt Beverages Ass'n, Trade Reg. Rep. (1957 Trade Cas.) If 68590 (W.D. Pa. Jan. 25, 1957).

60. Frankfort Distilleries v. United States, 144 F.2d 824, 830 (10th Cir. 1944) (citing numerous cases).

61. Courts often speak of the necessity to outline in the indictment the particular plan of the defendants - whether it was to divide markets, fix prices, coerce others to join a price-fixing association. See, e.g., United States v. Greater Blouse, Shirt and Neckwear Contractors Ass'n, Trade Reg. REP. (1959 Trade Cas.), $\llbracket 69454$ (S.D.N.Y. Oct. 2, 1959). 
standing variances in the proof such as those suggested above.62 But the flexibility of the law of variances should not alter the fact that one who pleads guilty to an indictment before trial pleads guilty to the offense described in the indictment and not to some variation thereof which might have been established at trial.

Whether details in an indictment are "essential" to the charge is a matter which ultimately rests on the interpretation of the indictment by the court deciding the estoppel question. ${ }^{63}$ Having nothing to guide it except the prior judgment, the indictment, and the plea, such a court must be heavily influenced by the terminology employed in the indictment. In two recent cases, for example, courts which narrowly restricted the scope of estoppel of guilty pleas to conspiracy indictments suggested that their decisions would have been broader had the indictments been framed differently. In United States $v$. Guzzone, ${ }^{64}$ the Government, following a criminal conviction for conspiracy to file false claims, brought a civil suit to recover $\$ 2000$ statutory forfeitures under the Surplus Property Act. When the Government sought to introduce the criminal indictment and plea of guilty as conclusive of nine overt acts, the court refused this construction, saying in part:

The indictment further alleged that in pursuance of said conspiracy the - defendants committed nine overt acts, each of which had to do with one or more named veterans.

No substantive counts were included in the indictment. The defendants were not charged with unlawfully obtaining surplus trucks, but with conspiracy to cause the veterans to file false statements [footnoting the statute]. The pleas admitted this and estopped the defendants from denying it in the government's civil action. Whether or not the veterans purchased trucks and transferred them to defendants (although admissible evidence in the criminal trial) was not necessary to establishment of the conspiracy charged and allegations that they did so were superfluous. ${ }^{65}$

62. Berger v. United States, 295 U.S. 78 (1935). The problem here was that one conspiracy was alleged and two proved. Only one involved the defendant; the Supreme Court held this variance not prejudicial. See generally Note, 57 CoLuM. L. REv. 387 (1957).

63. The court's task could be compared to that of the court passing on the sufficiency of the Sherman Act indictment. Both must decide what allegations are necessary to define the particular conspiracy. But the similarity is superficial, as exemplified by the complete reversal of the defendant's position in the two cases. The defendant challenging the sufficiency of the indictment seeks to have the conspiracy defined in explicit detail while the defendant in an estoppel case would argue that only the most general charging terms were necessary to define the conspiracy. What in fairness to defendant would be sufficient to allege a conspiracy which he could defend against might be considerably more than would be necessary to define a specific crime for estoppel purposes. On the other hand, the language in some cases passing on sufficiency which indicates that very little description is necessary does not mean that much description is surplussage or extraneous. Other reasons, such as the availability of a bill of particulars, may influence the court's holding sufficient an indictment with few specifics.

64. 273 F.2d 121 (2d Cir. 1959).

65. Id. at 123. (Emphasis added.) 
This language indicates that if the criminal indictment had incorporated the actual acquisition of trucks as part of the conspiracy, the defendant's guilty plea might have estopped their denial of acquisition. But even if the indictments had been framed as the court hints, this would not solve the problem of which overt acts were admitted when nine were charged and only one was necessary for conviction. United States v. Ben Grunstein \& Sons Co. ${ }^{66}$ provides a possible guide for drawing a multi-overt acts indictment:

If . . . the bribery allegation is but . . . one of the many 'means ... effectuating the conspiracy,' the plea does not constitute an admission of his bribery ... if the bribery ... alleges one of the essential characteristics of the indictment pleaded to ... the plea would have admitted it. ${ }^{67}$

Other dictum in the same case draws a line between acts set out as actually having effectuated the conspiracy and those which "could also be read as simply characterizing the illegal plan which defendants had in mind, as distinguished from the effectuation of such plan ...."08 The implication is that acts alleged "as part of" an effectuated conspiracy would have estoppel value not otherwise given. To the extent that these various ways of expressing details conform to the actual conspiracy, the terminology of the indictment rightly persuades the court. Unfortunately, but inevitably, the court which has no other means for defining the scope of the prior judgment cannot with certainty distinguish the artful from the accurate indictment.

The difficulty of interpreting a former judgment without the aid of a trial record ${ }^{60}$ and the realization that guilty pleas frequently result from considerations extraneous to the actual guilt of the defendant ${ }^{70}$ may also lead courts

66. 127 F. Supp. 907 (D. N.J. 1955).

67. Id. at 910 .

68. Ibid.

69. There may be hesitancy as well as difficulty in applying estoppel on the basis of pleas rather than trial of the issues. The rationale of estoppel is intimately tied to its salutary effect in preventing re-litigation of issues already fought out. Scott, Collateral Estoppel by Judgment, 56 HaRv. L. Rev. 1, 3 (1942); cf. Restatenent, Judgments § 68, comment $i$ (1942). This is especially true of collateral estoppel which, unlike res judicata, applies only to matters actually determined and not to those which might have been litigated. Courts may feel that a guilty plea is not a "litigation" of any issues; and though it might be appropriate for res judicata since there was an opportunity to litigate, the plea is less suitable for estoppel purposes. But cf. cases cited at note 51 supra. Analogous are cases holding that collateral estoppel does not apply to default judgments since no issues have been litigated. See, e.g., Lovejoy v. Ashworth, 94 N.F. 8, 45 A.2d 218 (1946).

70. Typical explanations of why defendant pleaded guilty appear in Minasian v. Aetna Life Ins. Co., 295 Mass. 9, 3 N.E.2d 17 (1936) (advice of counsel and desire to dispose of criminal case speedily) and Gillespie v. Modern Woodmen of America, 101 W. Va. 602, 133 S.E. 333 (1926) (pleaded guilty to lesser violation to avoid risk of conviction on plea of not guilty to greater offense).

Legislative recognition that failure to defend against a criminal charge does not necessarily mean the defendant is guilty may be inferred from laws which make former convictions of traffic violations inadmissible in damage actions related to the violations. See, e.g., Mrnn. Stat. Ann. \& 169.94(1) \& (7) (1941). In such cases defendants might 
basing estoppel on only an indictment and a plea to take a restrictive view. Thus, in the electrical cases, the courts could easily follow the few cases which have already passed on the scope of conspiracy guilty pleas, ${ }^{71}$ and hold the companies estopped only as to the statutory definition of the crime alleged in Paragraph 9.72 A court which desired to hold defendants estopped more broadly, however, could reasonably define the conspiracy only by reference to the terms set out in Paragraph 10. This paragraph alleges a number of different conspiracies, ${ }^{73}$ against different classes of consumers $\mathbf{7}^{74}$ proof of any one of the elements would have been sufficient for a conviction. But a court seeking a common sense definition of the particular conspiracy involved in the relevant case, rather than any conspiracy in general, might be willing to estop defendants from denying the allegations of this paragraph. Certainly, it is doubtful whether any court would grant the estoppel effect to the particular acts and results alleged in Paragraphs 12 and 13.

But different considerations come to bear on the question of what scope guilty pleas should have as common law admissions. In both severity of impact and doctrinal rationale, admissions differ radically from estoppel. An admission may be rebutted while estoppel forecloses any further discussion of the matters covered. Moreover, admission doctrine focuses on the plea as defendants' statement rather than the judgment as the statement of a third party. ${ }^{70}$ As defendants' voluntary statement, there is no reason why the plea should be legally incapable of embracing matter more extensive than that on which estoppel would be given. Defendant's presence in the second courtroom affords him an opportunity to counter that which the plea is deemed to cover, and to bring forth any considerations, other than actual guilt, which influenced the plea. Thus, no rigid notion of essentiality is necessary to insure opportunity to litigate all issues.

often prefer pleading guilty and paying a small fine rather than litigating to the utmost in the magistrates' court. See Warren v. March, 215 Minn. 615, 11 N.W.2d 528, 531 (1943). But cf. Indo v. Woodbury, 8 N.Y.2d 165 (1960). A possible analogy might be drawn to the anti-trust cases where the criminal sanctions are relatively insignificant but the trials are expensive and time-consuming.

It was pointed out in Note, 50 Y ALE L.J. 499, 505 (1940) that:

A plea of guilty, ostensibly more convincing proof of guilt than a conviction after trial, may often be made by one who is able to obtain acquittal but is induced by extrinsic circumstances to capitulate

citing Report of the N.Y. State Crime Comimssion 129-32 (1927), Fuller, Criminaz Justice in Virginia 85 (1931), Criminal Justice in Cleveland 236 (1927), Misssouri CrIne SuRvey 276 (1926).

71. See note 52 sipra.

72. See text at note 45 supra.

73. "1) To fix and maintain prices; 2) To allocate . . . the business of supplying circuit breakers to ... government agencies; 3) To submit ... rigged bids ...." See text at note 45 supra.

74. Industrial users, Federal Government, private utilities, and municipalities. Ibid.

75. See, e.g., Globe \& Rutgers Fire Ins. Co. v. Foil, 189 S.C. 91, 200 S.E. 97 (1938); Wesnieski v. Vanek, 99 N.W. 258, 260 (1904). 
Since the effect of an admission varies so profoundly from that of estoppel, the task of the court differs in justly defining the conspiracy. A defendant who has pleaded guilty should be held, for common law admission purposes, to have admitted all the allegations of the indictment. Under this rule, the guilty plea in the electrical cases, for example, would be held to be admissions embracing the specific meetings and other material in Paragraphs 11 and 12.0 Defendants could then introduce motions to strike improper allegations which they made when they pleaded guilty, or exculpatory statements, ${ }^{77}$ as well as other evidence tending to disprove the truth of the whole or any part of the indictments. But the introduction of the pleas alone would be sufficient to shift to the defendants the burden of going forward with evidence.

This procedure would probably increase the frequency of plaintiff recovery in treble damage actions, ${ }^{78}$ which would not be an undesirable result. Though the treble damage suit is the only potentially effective deterrent to many types of antitrust violations, ${ }^{79}$ plaintiff recovery in the past has been infrequent and insubstantial. ${ }^{80}$ Many courts have recently lowered barriers to recovery by eliminating such defenses as "passing on," "pari delicto" and "unclean hands," and by reducing plaintiff's burden of proving with "certainty" a direct and proximate "causal relationship between violation and damages." 11 In the context of these judicial developments it is reasonable to adopt a procedure which reduces the initial burden of third party plaintiffs claiming injury from a formally admitted conspiracy, but which does not deny defendants the opportunity fully to litigate any issue.

76. See note 45 supra.

77. These pleas of guilty, are not, of course, an admission of all the allegations of the indictment; they are made to terminate what would otherwise be a most protracted and expensive litigation.

Counsel for General Electric, Transcript, supra note 1, at 393.

What limitations a pleading defendant may impose upon subsequent use of the plea will be a question raised by the introduction of these statements. A possible analogy is the rule which makes judgment on a plea of nolo contendere a conviction for "second offender" statutory purposes. Almost by definition, pleading nolo is an attempt to limit any subsequent effect of the plea. Yet conviction on a nolo plea is counted a prior offense in many jurisdictions. See, e.g. People v. Daiboch, 265 N.Y. 125, 191 N.E. 859 (1934). The fact of judgment and all elements necessary to the fact may be beyond the defendant's power to limit or deny.

78. But cf. Note, Clayton Act, Section 5: Aid to Treble-Damage Suitors, 61 YALE L.J. 417,425 (1952) which suggests that unless the prior judgment is admitted as conclusive evidence, the private litigant's lot remains unhappy.

79. See, e.g., Loevinger, Private Action-The Strongest Piller of Antitrust, 3 ANTITRUST Bull. 167 (1958); Comment, Increasing Control Over Corporate Crine-A Problem in the Law of Sanctions, 71 YaLE L.J. 280, 288-290 (1961).

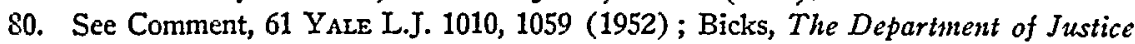
and Private Treble Damage Actions, 4 Antitrust Bull. 5 (1959).

81. See Sunkist Growers, Inc. v. Winckler \& Smith Citrus Prods. Co., 284 F.2d 1, 32 (9th Cir. 1960) (citing cases). For analysis, see Note, 70 YALE L.J. 469, 477-78 (1961); ABA, An Antirrust Handbaok 578-80 (1958). See also, Clark, The Treble Damage Bonanza: New Doctrines of Damages in Private Antitrust Suits, 52 Mrcr. L. REv. 363 (1954) ; Note, 61 YALE L.J. 1010 (1952). 